\title{
Antibiotic resistance of Staphylococcus aureus associated with subclinical and clinical mastitis in Uruguay during an eight-year period
}

\author{
Rosario I. de los Santos ${ }^{\mathrm{a}}$, Pablo M. Zunino ${ }^{\mathrm{b}}$, Andrés D. Gil ${ }^{\mathrm{a}}$, Adolfo Laport ${ }^{\mathrm{c}}$, Darío J. Hirigoyen ${ }^{\mathrm{c}, \mathrm{d}}$
}

\begin{abstract}
Records of in vitro susceptibility tests performed between 2008 and 2015 were retrospectively reviewed in order to evaluate the dynamic profiles of possible changes in antimicrobial resistance of Staphylococcus aureus isolated from milk samples of cows with subclinical mastitis from 12 different Uruguayan Provinces. The results of 1,631 isolates tested by disk diffusion technique for susceptibility to penicillin and erythromycin were analysed. The possible tendency or changes in the behaviour of this pathogen against penicillin and erythromycin in the 8 year period was evaluated using the chi-square tests for trend and the homogeneity. The highest rate of resistance was observed for penicillin (36.9\% in 2010), while erythromycin showed a resistance rate significantly lower (5.7\% in 2015). The test for trend showed a significant trend towards decreased resistance to penicillin, whereas for erythromycin an increased resistance trend was observed. The determination of the scope of the problem is essential for the formulation and monitoring of effective response to anti-microbial resistance (AMR). Antibiotic assessment in Uruguay is now being reviewed with the objective of limiting antibiotics prescription to professionals trained to select a successful therapy, choosing the appropriated drug and treatment duration according each situation. To generate knowledge on the magnitude and tendency of the AMR problem using country-specific information must be a priority.
\end{abstract}

Key words: Staphylococcus aureus, mastitis, antibiotics, Uruguay.

RESUMEN. Los registros de las pruebas de susceptibilidad in vitro realizadas entre 2008 y 2015 fueron revisados retrospectivamente con el fin de evaluar los perfiles dinámicos de posibles cambios en la resistencia antimicrobiana de Staphylococcus aureus aislados de muestras de leche de vacas con mastitis subclínica de 12 provincias uruguayas. Se analizaron los resultados de 1.631 aislamientos mediante la técnica de difusión en disco para la susceptibilidad a penicilina y eritromicina. La posible tendencia o cambios en el comportamiento de este patógeno frente a la penicilina y la eritromicina en el período de ocho años se evaluó utilizando las pruebas de chi-cuadrado para la tendencia y la homogeneidad. La mayor tasa de resistencia se observó para penicilina (36,9\% en 2010), mientras que eritromicina mostró una tasa de resistencia significativamente menor (5,7\% en 2015). El resultado de la prueba de tendencia fue significativo, indicando una disminución de la resistencia a la penicilina, mientras que para la eritromicina se observó una tendencia a aumentar la resistencia. Determinar el alcance del problema es esencial para la formulación y el seguimiento de la respuesta eficaz a la resistencia antimicrobiana (RAM). La evaluación de antibióticos en Uruuguay está siendo revisada con el objetivo de limitar la prescripción de antibióticos a los profesionales capacitados para seleccionar una terapia exitosa eligiendo la droga apropiada y la duración del tratamiento de acuerdo con cada situación. Generar conocimientos con información específica del país respecto de la magnitud y las tendencias del problema de RAM debe ser una prioridad.

Palabras clave: Staphylococcus aureus, mastitis, antibióticos, Uruguay.

\section{INTRODUCTION}

Staphylococcus aureus is a Gram-positive, facultative anaerobic, non-motile, non-sporulating, catalase-positive and coagulase-positive coccus that is generally regarded as one of the major etiologic agents of subclinical, clinical, recurrent and chronic mastitis in dairy cattle (Dias et al 2013, Jagielski et al 2014). This pathogen has the potential to develop resistance to almost all the antimicrobial agents used for the management of the disease (Barkema et al 2009, Hiramatsu et al 2001). S. aureus is also well known

Accepted: 30.06 .2017 .

aDepartments of DairyScience and Technology and Biostatistics and Informatics of Veterinary Faculty, Universidad de la República, Montevideo, Uruguay.

${ }^{b}$ Department of Microbiology, Instituto de Investigaciones Biológicas Clemente Estable, Montevideo, Uruguay.

${ }^{\mathrm{c} C}$ Cooperativa COLAVECO, Nueva Helvecia, Colonia, Uruguay.

${ }^{d}$ National Institute of Agricultural Research La Estanzuela, Colonia, Uruguay.

*Corresponding author: R de los Santos; A. Lasplaces 1550, Montevideo 11600, Uruguay; rosario.rdelos@gmail.com for its tolerance to a wide range of adverse circumstances. This tolerance is related to diverse genetic capabilities including the ability to form biofilms in the host, which contributes to the resistance of this microorganism against antibiotics (Brady et al 2011, Kenar et al 2012).

Mastitis is the major infectious disease in dairy herds and it is responsible for major economic losses in the milk industry. Besides financial implications, the importance of mastitis in public health should not be disregarded. The extensive use of antibiotics in the treatment and control of mastitis (Erskine et al 2002, San Martín et al 2002) has possible implications for human health through an increased risk of antibiotic bacterial resistant strains emergence that may enter the food chain (Pol and Ruegg 2007, Ruegg et al 2015).

Antibiotics in Uruguay are prescribed by veterinarians, but farmers also could acquire them without a prescription and use them based on the advice of other farmers. However, it is interesting that this study was conducted based on a cows population that has been monitored with sensibility tests over time (8 years), showing care in the prevention of misuse of antibiotics. 
Penicillin and erythromycin are antibiotics frequently used in mastitis treatment. Penicillin is the drug of choice for $S$. aureus mastitis treatment in Uruguay, if $S$. aureus is sensitive to it and the only to find out is to perform a susceptibility test. In this work, the efficiency of penicillin to provide a successful treatment based on sensibility test results, seems to increase through the years. Erythromycin belongs to the group of macrolides that acts in the bacteria cell in a different way than penicillin and has a good distribution in the mammary gland. Therefore, it is often used in the mastitis treatment, as an alternative treatment for $S$. aureus mastitis.

During the period 2008-2015 we observed that the only two antibiotics used that maintained a regular frequency of use, under the conditions of our study, were penicillin and erythromycin. In other words, others antibiotics have been discard from this study based on a temporal trend of resistance, due to a lack of information during several months of the studied period.

The objective of the present study was to evaluate the susceptibility of $S$. aureus strains isolated from milk samples from cows with subclinical and clinical mastitis from 12 different Uruguayan Provinces, against penicillin and erythromycin throughout an eight-years period.

\section{MATERIAL AND METHODS}

Data were obtained from records of bovine milk samples analysed between January 2008 and December 2015 in three diagnostic services: COLAVECO Laboratory, Nueva Helvecia, Colonia, Uruguay; Department of Microbiology at the Institute of Biological Research "Clemente Estable", Uruguay; and the Department of Dairy Science and Technology, Faculty of Veterinary Sciences, University of Uruguay.

Individual quarter milk samples were collected by veterinarians according to the recommendations of the National Mastitis Council (1999). Milk samples were collected from 80 dairy farms distributed among the Uruguayan Provinces of Canelones, Colonia, Flores, Florida, Montevideo, Rocha, Río Negro, San José, Soriano, Tacuarembó, Paysandú, and Durazno.

Eighty-five percent of the cows were sampled once a year, $14 \%$ twice a year and $1 \%$ more than twice a year. The median of isolates per farm per year was 3, the lower quartile was 1 and the upper quartile was 5 . The microorganisms were isolated from the milk samples of animals that suffered subclinical or clinical mastitis $(78 \%$ and $22 \%$ respectively).

The samples were cultured on blood agar and incubated aerobically at $37{ }^{\circ} \mathrm{C}$ for $48 \mathrm{~h}$ (National Mastitis Council 1999). Bacterial identification was performed using standard morphological analysis and biochemical tests (Hoet et al 1999, National Mastitis Council 1999).

A collection of 1,631 S. aureus isolates was generated and analysed during the whole study period.
The antimicrobial susceptibility tests were performed using the method of agar disk diffusion (Bauer et al 1966) for erythromycin $(15 \mu \mathrm{g})$ and penicillin $(10 \mu \mathrm{g})$ and the results were analysed in accordance with the Clinical and Laboratory Standards Institute (2011).

Isolates were classified as susceptible, intermediate or resistant to antimicrobials. In order to facilitate the data interpretation, intermediate results were considered resistant. For quality control of the susceptibility tests, the reference strain $S$. aureus ATCC 25923 was used (Treangen et al 2014).

The trend of $S$. aureus resistance to penicillin and erythromycin in the studied period was evaluated using a chi-square test for trend and the differences of proportion of resistance for the chi-square test for homogeneity. The significance level selected was a $P$-value of 0.05 .

These analyses were performed using Stata/SE software. The analysed variables were resistance to penicillin or to erythromycin and the year of the isolation from 2008 to 2015 inclusive was considered as the ordinal variable. The status of each isolate was coded as a binary variable $(0 / 1$; $0=$ susceptible and $1=$ resistance).

\section{RESULTS AND DISCUSSION}

Over the 8-year period considered, the annual proportion of $S$. aureus isolates (78\% from subclinical and $22 \%$ from clinical mastitis cases) that were resistant to penicillin significantly decreased $(P<0.05)$. The annual proportion of $S$. aureus isolates that were resistant to erythromycin showed a score trend to increase resistance in isolated $S$. aureus $(51 / 1631)$ during the considered period $(P<0.05)$ (table 1).

The overall percentage of resistance to penicillin was $24.4 \%$ in the 8 years period and a negative trend of resistance was observed. On the other hand, for erythromycin an overall percentage of $3.1 \%$ resistance was determined in the same period, but the score trend and the odd ratios (OR) suggest an increased resistance of $S$. aureus to this antibiotic.

It was observed that the proportion of resistance to penicillin during the years 2009, 2010 and 2011 were not significantly different from 2008, but in subsequent years a significant drop in resistance was observed and traduced into odds ratios (OR) less than 1. The chi- square score trend and the OR indicates, for penicillin, an overall trend of risk reduction over the years $(P<0.05)$.

For erythromycin, the homogeneity test don't reject the null hypothesis, so the differences in the proportion are not significant, but the score test for trend of odds are significant $(P<0.05)$. During 2009 the of resistance erythromycin increased compared to 2008, in 2010 and 2011 we determined a minor resistance compared to 2008 and during the period 2012/2014 each year the resistance was superior than in 2008, with the greatest isolated trend of resistance in 2015 . 
Table 1. Percentage of resistant S. aureus strains recovered from milk samples of cows with clinical and subclinical mastitis (2008-2015).

\begin{tabular}{|c|c|c|c|c|c|c|c|c|c|c|c|c|}
\hline \multirow{2}{*}{\multicolumn{2}{|c|}{$\begin{array}{c}\text { Antimic } \\
\text { agent }\end{array}$}} & \multicolumn{8}{|c|}{ Year } & \multirow{2}{*}{ Total } & \multirow{2}{*}{$\mathrm{H}^{1}$} & \multirow{2}{*}{ T.S. ${ }^{2}$} \\
\hline & & 2008 & 2009 & 2010 & 2011 & 2012 & 2013 & 2014 & 2015 & & & \\
\hline \multirow{3}{*}{$\begin{array}{l}: \Xi \\
\stackrel{\Xi}{0} \\
\stackrel{\Xi}{0} \\
.\end{array}$} & $\%$ & 36.8 & 46.3 & 36.9 & 35.9 & 31.1 & 28.3 & 13.8 & 8.4 & 24.4 & $<0.05$ & $<0.05$ \\
\hline & Resist/N & $(53 / 144)$ & $(56 / 121)$ & $(64 / 173)$ & $(37 / 103)$ & $(46 / 148)$ & (47/166) & $(76 / 549)$ & (19/227) & $398 / 1631$ & & \\
\hline & O.R. & 1.00 & 1.48 & 1.02 & 0.96 & 0.27 & 0.38 & 0.18 & 0.16 & & & \\
\hline \multirow{3}{*}{ 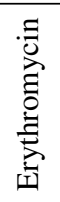 } & $\%$ & 2.1 & 3.3 & 1.2 & 1.0 & 4.7 & 1.2 & 3.5 & 5.7 & 3.1 & N.S. & $<0.05$ \\
\hline & Resist/N & $(3 / 144)$ & $(4 / 121)$ & $(2 / 173)$ & $(1 / 103)$ & $(7 / 148)$ & $(2 / 166)$ & (19/549) & $(13 / 227)$ & $51 / 1631$ & & \\
\hline & O.R. & 1.00 & 1.61 & 0.55 & 0.46 & 1.72 & 1.03 & 2.25 & 2.83 & & & \\
\hline
\end{tabular}

Notes: 1. H means "Homogenity"; 2. T.S. means "Trend Score".

The numbers represent the percentage of resistant strains, the numbers in brackets indicate the frequency of resistant strains.

The comparison of susceptibility patterns evolution results is complex, and conclusions should be carefully considered. This can be explained by methodological differences (criteria for selection of cow or bacteriological methods) or regional differences in pathogen populations (Erskine et al 2002). Nevertheless, the results of the present study seem to agree with those reported for Staphylococcus aureus by other authors.

Erskine et al (2002) conducted a retrospective analysis (1994 to 2000) of 2,778 mastitis isolates from milk samples submitted for pathogen isolation and antibiotic susceptibility determination using the ADD method. The authors reported no significant temporal changes in susceptibility for the majority of the examined species (Streptococcus uberis, Streptococcus dysgalactiae, Streptococcus agalactiae, Escherichia coli, Klebsiella pneumoniae, Serratia marcesens, and Pseudomonas aeruginosa). The exception for Erskine et al (2002) work was $S$. aureus resistance trend determined as significative: for this bacterium a decrease in resistance for penicillin from bovine mastitis cases of clinical and subclinical mastitis, during the period 1994 to 2000 , decreased from $61.6 \%$ in 1994 to $39.1 \%$ in 2000 . Resistance trend reported for erythromycin was in 1994 $25 \%$ and $4.5 \%$ in 2000 .

Using a similar approach, Makovec and Ruegg (2003), did not find significant changes in Gram-positive mastitis pathogens susceptibility for most antimicrobial-pathogen combinations for the period 1994 to 2001; for S. aureus isolates a decrease in resistance from 49 to $30 \%$ is reported. In agreement, Barlow (2011) reported an increase in the proportion of $S$. aureus isolates susceptible to ampicillin, penicillin and erythromycin.

Conversely, other studies showed an increase in bacterial resistance of mammary pathogens to the antimicrobials commonly used in mastitis. In Finland, the prevalence of bovine mastitis was surveyed during 1988, 1995, and 2001. These studies showed a decrease in mastitis prevalence from $47.8 \%$ in 1988 to $37.8 \%$ in 1995 , and $30.6 \%$ in 2001 , being staphylococci the largest group of isolated pathogens. When antimicrobial susceptibility was analysed, it was observed that although the proportion of $S$. aureus decreased, a significant increase in the proportion of strains resistant to at least one antibacterial drug increased (from $36.9 \%$ in 1988 to $63.6 \%$ in 1995, and to $68.9 \%$ in 2001). The same holds true for multiresistant strains; but in this case, it was proportional to the overall increase in resistance (Myllys et al 1998, Pikälä et al 2004).

Regarding the percentage of penicillin-resistant $S$. aureus strains in the present study (24.4\%) it seems lower than those previously reported for bovine isolates in Uruguay and other countries (Giannecchini et al 2016). Those differences may be attributed to the number of samples processed in the studies (n), the regional use of antibiotic therapy, country regulations on antimicrobial use, traditions of the farmer, and the evolution of resistance among local microbiota under therapy selection pressure.

As previously mentioned, this is the first study that assessed the resistance trend of $S$. aureus isolated from cow's milk samples associated with clinical (22\%) and subclinical (78\%) in Uruguay. This data showed the $S$. aureus resistance has changed over time in a different direction for penicillin and erythromycin, so further studies are needed on managing the differences between these 2 antimicrobials to identify the potential risk factors for these association.

Bacteria susceptibility against both selected antibiotics showed a different evolution along the study period. This indicates, in first place, that the use of specific antibiotics must be monitored as a good practice to improve the effectiveness of the drug.

The use of penicillin for $S$. aureus mastitis, strictly associated with bacterial susceptibility tests, remains to be a good option for a successful treatment. It is interesting to note that this study was conducted based on a cow population that was monitored for a considerable long 
period ( 8 years) through regular bacterial susceptibility tests, suggesting that this strategy could impact in the prevention of antibiotics misuse.

Obtained data are highly important since the knowledge of local resistance patterns is fundamental for the design of effective treatment strategies. The evolution of antibiotic resistance implicate the efficiency of the installed therapy decisions. This survey allows to improve critical decisions, make corrections of the wrong use of antibiotics and preserve public health and dairy industry. An assessment of antibiotic in our country is now being reviewed with the objective of limiting this kind of resources to professionals such as doctors and veterinarians who are trained to select a successful therapy choosing the appropriated drug and treatment duration.

\section{REFERENCES}

Barkema H, Green M, Bradley A, Zadoks R. 2009. Invited review: The role of contagious disease in udder health. J Dairy Sci 92, 47174729; doi: 10.3168/jds.2009-2347.

Barlow J. 2011. Mastitis therapy and antimicrobial susceptibility: A multispecies review with a focus on antibiotic treatment of mastitis in dairy cattle. J Mammary Gland Biol Neoplasia 16, 383-407. DOI:10.1007/s10911-011-9235-z.

Bauer A, Kirby W, Sherris J, Turck M. 1966. Antibiotic susceptibility testing by a standardized single disk method. Amer J Clin Pathol 45, 493-496.

Brady R, O’May G, Leid J, Prior M, Costerton J, et al. 2011. Resolution of Staphylococcus aureus biofilm infection using vaccination and antibiotic treatment. Infect Immun 79, 1797-803. DOI: 10.1128/ IAI.00451-10.

Clinical and Laboratory Standards Institute. 2011. Performance Standards for Antimicrobial Susceptibility Testing; Twenty-First Informational Supplement. Clinical and Laboratory Standards Institute, Wayne, PA, USA.

de los Santos R, Fernández M, Carro S, Zunino P. 2014. Characterization of Staphylococcus aureus isolated from cases of bovine subclinical mastitis in two Uruguayan dairy farms. Arch Med Vet 46, 315-30120.

Dias RS, Eller MR, Duarte VS, Pereira ÂL, Silva CC, et al. 2013. Use of phages against antibiotic-resistant Staphylococcus aureus isolated from bovine mastitis. J Anim Sci 91, 3930-3939. DOI: 10.2527/ jas.2012-5884.

Erskine RJ, Walker R, Bolin C, Bartlett P, White D. 2002. Trends in antibacterial susceptibility of mastitis pathogens during a seven-year period. J Dairy Sci 85, 1111-1118.
Giannecchini R, Concha C, Delucci I, Gil J, Salvarrey L, et al. 2014. Mastitis bovina, reconocimiento de los patógenos y su resistencia antimicrobiana en la Cuenca Lechera del Sur de Uruguay. Veterinaria, Montevideo 50, 4-32.

Hiramatsu K, Cui L, Kuroda M, Ito T. 2001. The emergence and evolution of methicillin-resistant Staphylococcus aureus. Trends Microbiol 9, 486-493. DOI: 10.1016/S0966-842X(01)02175-8.

Hoet A, D'Pool G, Fulcado W, Polo R, Graterol C, et al. 1999. Aislamiento de estafilococos coagulasa positivos, distintos a Staphylococcus aureus, de cuartos con mastitis subclínica en la Villa del Rosario, Estado Zulia, Venezuela. Rev Científica FCV-LUZ IX, 149-153.

Jagielski T, Puacz E, Lisowski A, Siedlecki P, Dudziak W, et al. 2014. Short communication: Antimicrobial susceptibility profiling and genotyping of Staphylococcus aureus isolates from bovine mastitis in Poland. J Dairy Sci 97, 6122-6128.

Kateete D, Kimani C, Katabazi F, Okeng A, Okee M, et al. 2010. Identification of Staphylococcus aureus: DNase and mannitol salt agar improve the efficiency of the tube coagulase test.; Ann Clin Microb Anti 9, 23. DOI:10.1186/1476-0711-9-23

Kenar B, Kuyucuoğlu Y, Şeker E. 2012. Antibiotic susceptibility of coagulase-negative Staphylococci isolated from bovine subclinical mastitis in Turkey. Pak Vet J 32, 390-393.

Makovec JA, Ruegg PL. 2003; Antimicrobial resistance of bacteria isolated from dairy cow milk samples submitted for bacterial culture: 8,905 samples (1994-2001). J Am Vet Med Assoc 222, 1582-1589.

Myllys V, Asplund K, Brofeldt E, Hirvela- Koski V, Honkamen-Buzalski T, et al. 1998. Bovine mastitis in Finland in 1998 and 1995 - changes in prevalence and antimicrobial resistance. Acta Vet Scand 39, 119-126.

National Mastitis Council. 1999. Laboratory Handbook on Bovine Mastitis. Revised ed. Natl Mastitis Counc, Inc., Madison, Wisconsin USA.

Pikälä A, Haveri M, Pyörälä S, Myllys V, Honkanen-Buzalski T. 2004. Bovine mastitis in Finland 2001-Prevalence, distribution of bacteria, and antimicrobial resistance. J Dairy Sci 87, 2433-2441.

Pol M, Ruegg P. 2007. Treatment practices and quantification of antimicrobial usage. J Dairy Sci 90, 249-261.

Ruegg P, Oliveira L, Jin W, Okwumabua O. 2015. Phenotypic antimicrobial susceptibility and occurrence of selected resistance genes in gram-positive mastitis pathogens isolated from Wisconsin dairy cows. J Dairy Sci 98, 4521-4534.

San Martín B, Kruze J, Morales MA, Agüero H, León B, et al. 2002. Bacterial resistance of mastitis pathogens isolated from dairy cows in the $\mathrm{V}^{\text {th }}$ Region, Metropolitan Region and $\mathrm{X}^{\text {th }}$ Region, Chile. Arch Med Vet 34, 221-234.

Treangen T, Maybank R, Enke S, Friss M, Diviak L, et al. 2014. Complete Genome Sequence of the Quality Control Strain Staphylococcus aureus subsp. aureus ATCC 25923. Genome Announc 2:e01110-14.; DOI:10.1128/genomeA.01110-14. 